\title{
체간 훈련 운동이 만성기 뇌졸중 환자의 균형 및 에너지 소모에 미치는 효과 : 단일사례연구
}

\author{
정경만 ${ }^{*}$, 정유진 ${ }^{2}$, 김희한 ${ }^{3}$, 박상현 $^{4}$ \\ ${ }^{* 1}$ 원광대학교병원 물리치료실, ${ }^{2}$ 원광대학교병원 작업치료실, \\ ${ }^{3}$ 원광대학교병원 물리치료실, ${ }^{4}$ 정의원 물리치료실
}

The Effect of Trunk Training Exercise on Balance and Energy Expenditure in chronic Stroke Patients :

Single-subject research design

\author{
Kyeoung-Man Jung ${ }^{*}$, Yu-Jin Jung ${ }^{2}$, Hee-Han Kim ${ }^{3}$, Sang-Hyun Park ${ }^{4}$ \\ ${ }^{* 1}$ Dept. of physical Therapy, Won-kwang University Hospita, \\ ${ }^{2}$ Dept. of occupational Therapy, Won-kwang University Hospital \\ ${ }^{3}$ Dept. of physical Therapy, Won-kwang University Hospital \\ ${ }^{4}$ Dept. of physical Therapy, Jung Clinic
}

Purpose This study was to determine the effect of trunk training exercise on dynamic balance and energy expenditure during walk in chronic stroke patients. Methods This study used a single subject research design. Two chronic stroke patients were participated and received general training five times per week. The trunk training exercise program was modified from preceding studies and composed of trunk muscle strengthening and selective and coordinated movement. The subjects performed exercise program five times a week, forty minute a day, four weeks. Pre base line(A) was only collected participant information without intervention in 5 times. Trunk training exercise(B) was carried out 10 times and 5 times to base lime(A) after intervention. The dynamic balance of was evaluated by Timed Up and Go Test(TUG), the energy consumption was measured by the oxygen cost as the oxygen consumption per unit distance, energy expenditure index(EEI) as the difference of heart rate, in a session. Results The results of the evaluation in each subject were indicated that the dynamic balance test was improved, both oxygen cost and energy expenditure index were decreased during the intervention period. These effects were maintained even during the regression baseline period. Conclusion These results showed that trunk training exercise was effective in the improvement of dynamic balance and decrease energy consumption. This study suggests that trunk training exercise is effective in the improvement of energy efficiency during walk in chronic stroke patients.

Key words Dynamic balance, Energy expenditure, Oxygen cost, Stroke, Trunk training exercise

Corresponding author Kyeoung-Man Jung (future1347@naver.com)
Received date
2 August 2017
Revised date
2 October 2017
Accepted date
17 October 2017

\section{I. 서 론}

뇌졸중 환자는 마비측의 근 약화, 감각운동 결손, 강직, 인지 장애, 균형장애로 인해 자세조절에 문제를 가지게 된다. ${ }^{1)}$ 뇌졸 중 후 손상측 체간근육 약화와 고유수용성감각의 저하는 균형 과 안정성을 방해하여 기능적 활동을 저하시킨다. ${ }^{2}$ 편마비 환 자들은 체간의 비대칭과 불안정하기 때문에 서 있거나 앉은 상 태에서 자세 흔들림이 증가하고 동적 안정성이 감소하며 체중

doi : http:dx.doi.org/10.17817/2017.10.17.111176
이동 능력이 제한된다. ${ }^{3)}$ 뇌졸중 환자의 체간 조절 장애는 균형, 보행, 호흡, 상지 기능 등 다양한 기능 제한을 초래하게 된다. ${ }^{4)}$ 뇌졸중 환자들은 중력에 대항해 균형을 유지하고 독립적 체간 조절능력을 재 습득 하는데 많은 어려움이 있기 때문에 재활과 정에서 체간 조절 능력 향상을 위한 중재는 중요하다. ${ }^{5}$

체간 조절(trunk control)은 신체를 수직선 상에 똑바로 세우고 체중 이동을 적절하게 조절하거나, 정적 및 동적 자세 조절이 요구되는 동안 기저면 내에 무게중심이 유지할 수 있도 록 하는 몸통 근육의 선택적 조절 능력이다. ${ }^{()}$뇌졸중 환자의 
체간 조절능력 정도는 향후 기능적 회복 정도를 예측할 수 있 는 중요 인자이며, 기능 회복을 위해 발병 초기부터 적극적인 체간 조절능력에 대한 중재가 필요하다. ${ }^{7)}$ 신체의 균형과 안정 성을 목적으로 활성화되는 체간 근육은 사지의 움직임이 발생 하기 이전에 활성화 되어 신체의 흔들림을 최소화하고 원위부 의 섬세하고 정확한 동작이 유발될 수 있도록 근위부의 안정성 을 제공한다. ${ }^{8)}$

인간의 보행 효율성 측면에서 보면, 하지는 대칭적이고 리 드미컬한 움직임이 중요한데, 이때 신체 무게중심은 작은 범위 내에 유지될 때 역학적 에너지와 생리적 에너지 소모가 최소화 되어 에너지 효율성이 최대화 될 수 있다. ${ }^{9)}$ 뇌졸중 환자는 비 대칭적인 자세로 불안정성이 증가하고 체중이동 능력이 저하되 기 때문에 무게중심을 낮추어 안정성을 확보하려는 균형전략을 사용하게 된다. 이때 굴근의 활성도가 과도하게 증가되어 정상 인에 비해 에너지 소모가 증가되므로 근 피로와 지구력의 문제 가 초래된다. ${ }^{10)}$ 피로는 뇌졸중 환자의 일상생활에 불편감을 초 래하는데, 발병 1 년경과 시 $69.5 \%$, 발병 2년 경과 시 $50 \%$ 에 서 피로를 호소하며, $27 \%$ 에서는 매일 불편감을 느낄 정도로 뇌졸중 후 피로는 삶의 질 저하에 많은 영향을 미친다. ${ }^{11,12,13)}$ 뇌졸중 환자는 신체적, 인지적 결손을 보상하기 위한 과도한 노력으로 심한 피로가 발생하는데, 특히 보행 중 에너지 소모 량은 정상인과 비교했을 때 두 배 정도 높다고 하였다. ${ }^{14)}$ 호흡 가스 분석을 통한 생리적 에너지소비의 측정은 기능적 수행능 력의 장애를 정량적으로 평가하는데 가장 객관적인 방법이며 15), 다양한 운동 중재 효과를 측정하는 방법으로 사용될 수 있 다. ${ }^{16)}$ Koyama 등 (2012) ${ }^{17)}$ 은 건강한 사람을 대상으로 트레드 밀 보행 시 바닥이 불안정한 신발을 착용하였을 때가 안정된 신발을 착용했을 때보다 불안정성이 증진되고 신체 흔들림이 증가하여 균형유지를 위한 근 활성도 증가로 에너지 소모가 증 가한다고 하였다. 따라서 균형 능력의 정도가 에너지 소모에 직접적으로 영향을 줄 수 있기 때문에 균형 능력을 증진할 수 있는 다양한 중재는 에너지 효율성 측면에서 중요한 요소라고 하였다. ${ }^{18)}$ Houdijk 등(2009) ${ }^{19)}$ 도 균형 능력과 에너지 소모량 사이에 직접적인 상관관계가 있음을 보고하였다.

뇌졸중 환자들을 대상으로 체간 조절능력 향상을 위한 선 행 연구들을 보면, 체간 움직임을 반복 훈련하여 선택적인 움 직임을 증진하는 방법 ${ }^{20,21)}$, 과제지향훈련 ${ }^{22,23)}$, 불안정한 지지 면을 제공하여 더 많은 체간 근육들을 동원하는 방법 ${ }^{7,24)}$, 균형 운동 기구를 이용한 방법 ${ }^{25,26)}$ 등이 보고 되고 있다.

뇌졸중 환자를 대상으로 체간 훈련 운동에 대한 균형 능력 과 체간조절능력의 효과들이 입증되고 있음에도 불구하고 체간 훈련 운동이 에너지 소모에 미치는 연구는 아직까지 미흡하다. 또한 뇌졸중 환자를 대상으로 치료적 중재 후 에너지 효율성 측면에서 보행 장애와 기능적 수행능력의 변화에 대한 객관적
이고 양적인 측정 자료는 더욱 부족한 실정이다. 이에 본 연구 는 체간 훈련 운동이 만성 뇌졸중 환자의 균형 능력과 에너지 소모에 미치는 영향을 단일 사례 연구를 통해 확인한 후 향후 연구에 대한 기준을 제시하고자 한다.

\section{II. 연구 방법}

\section{1. 연구대상}

본 연구는 2015년 8월 1일 2015년 9월 30일까지 전북 익 산에 소재한 $\mathrm{W}$ 대학병원 재활의학과에 입원하여 포괄적인 재활 치료를 받는 뇌졸중 환자를 대상으로 하였다. 연구의 대상자는 자기공명촬영(MRI) 결과 뇌졸중으로 진단받은 2 명의 뇌졸중 환자 중 대상자 1 은 만 57 세 남성으로 신장 $178 \mathrm{~cm}$, 몸무게 $68 \mathrm{~kg}$, 발병일로부터 32 주가 지난 우측 편마비 환자였고, 대상 자 2는 만 51세 여성으로 신장 $162 \mathrm{~cm}$, 몸무게 $56 \mathrm{~kg}$, 발병 일로부터 39주가 지난 좌측 편마비 환자였다(Table 1). 연구 대상자의 선정기준은 다음과 같다. 뇌졸중으로 진단받고 6 개월 이 경과한 자, 보행 보조 도구를 이용하여 10 분 이상 보행이 가능한 자, 정형외과적 문제가 없는 자, 한국형 간이 정신상태 검사(Mini Mental Status Examination-Korean version; MMSE-K)상 24점 이상인 자(Kwon과 Park, 1989)로 운동프 로그램 이해할 수 있는 자로 하였다. 대상자 1 의 도수근력검사 (Manual Muscle Test; MMT)상 어깨 관절(Shoulder joint) 과 팔꿉 관절(Elbow joint)의 움직임 모두 Poor Fair-이었 고, 손바닥 쥐기와 펴기 모두 Poor 이었다. 고관절(Hip joint) 과 무릎관절(Knee joint)에서는 Fair이었고, 발목 저측굴곡 (Plantarflexion)과 배측굴곡(Dorsiflexion)은 Poor+이었고, 관절 제한은 없었다. 환측 발목 관절의 경직 등급인 $\mathrm{MAS}$ (modified ashworth scale)를 측정한 결과 $\mathrm{G} 1+$ 이었다. 외 발 지팡이(Mono-cane)를 사용하여 보행이 가능하였고 보행 중 입각기 시 환측 무릎이 과신전 되어 대퇴사두근과 고관절 외전근 및 신전근의 수축이 부족하였고 유각기 시 발목 관절이 저측 굴곡되는 양상을 보였다. 대상자 2는 도수근력검사상 어 깨 관절과 팔꿉 관절의 움직임 모두 Fair- Fair이었고, 손바 닥 쥐기와 펴기 모두 Fair- 이었다. 고관절과 무릎관절에서는 Fair+이었고, 발목 저측굴곡과 배측굴곡은 Poor+이었고, 관절 제한은 없었다. 환측 발목 관절의 경직 등급을 측정한 결과 $\mathrm{G} 1$ 이었다. 네발 지팡이(Qudri-cane)를 사용하여 보행이 가능하 였고 보행 중 입각기 시 환측 발목 관절은 저측굴곡되는 양상 을 보였고, 환측 무릎은 과신전 되었고 골반은 전방 경사가 되 어 무게중심이 발의 앞쪽에 위치하고 있었다. 대상자 1 과 2 모 두 보행 보조 도구를 사용하여 독립적 보행이 가능함에도 불구 하고 체간손상척도 검사 시 총 23 점 만점에서 대상자 1 은 15 
점, 대상자 2 는 16 점으로 나타났으며 상부 체간과 하부 체간 사이의 선택적인 움직임 능력이 부족하였고 앉은 자세에서 동 적 조절 능력과 협응력 및 선택적인 움직임이 부족하였다. 또 한 앉은 상태에서 안정성의 한계(limits of stability)가 환측으 로 체중 이동 시 부족하였고 하부 체간의 선택적 움직임 결여 로 상부 체간의 긴장도와 보상작용이 증가된 상태를 보이고 있 었다. 정적 기립 시 양쪽 발에서 압력 중심점은 발의 앞부분에 집중되어 있었고, 원활한 체중 이동 능력이 제한되고 있었다. 따라서 발병 기간이 6 개월이 지났지만 체간의 선택적인 움직임 이 부족한 상태로 판단되어 체간 훈련 운동을 통해 체간 근육 과 하지 사이에 협응력, 선택적 움직임, 체간 근육의 고유수용 성감각 촉진 등을 목적으로 하는 중재 방법이 필요할 것으로 사료 되었다. 대상자들은 본 연구의 목적과 실험 일정에 대해 충분한 설명을 듣고 서면으로 연구 참여에 직접 동의한 자로 하였다.

\section{2. 연구절차 및 중재방법}

본 연구의 실험 디자인은 단일사례 연구방법(single-subject research design)중 $\mathrm{ABA}$ 설계를 사용하였다. 총 실험은 20 회기로 기초선 과정(Baseline phase) A와 회귀과정(Baseline phase) $\mathrm{A}^{\prime}$ 는 체간 훈련 운동 실시하지 않는 기간으로 각 5회 에 걸쳐 기초자료를 수집하였고, 중재과정(Intervention phase) $\mathrm{B}$ 는 체간 훈련 운동을 실시하는 기간으로 총 10 회, 1 일 1 회, 회당 40 분씩 운동 적용 후 기초자료를 수집하였다. 기 초자료 수집은 동적 균형능력을 알아보기 위해 일어나 걸어가
기 검사와 에너지 효율성을 알아보기 위해 산소 소모비와 에너 지소모지수를 초기 기초선 과정(A), 회귀과정( $\left.\mathrm{A}^{\prime}\right)$, 중재과정 (B) 동안 매일 측정 기록하였다. 모든 대상자는 재활의학과에 서 실시하는 모든 물리. 작업치료를 시행하였고, 오후 4 시부터 본 연구를 위한 중재와 모든 평가를 시행하였다. 측정 10 분 전 에는 편안한 자세로 쉬는 시간 갖도록 하였다. 가능한 모든 측 정과 중재 기간 동안에는 물 이외에 음식물을 섭취하지 않도록 권장하였다. 본 연구의 일관성을 유지하기 위해 운동과 평가를 담당하는 치료사는 각각 분리되었으며 경력 10 년 이상의 경력 을 가진 치료사로 배정하여 연구 절차에 맞게 진행하였다. 본 연구에 사용된 체간 훈련 운동 프로그램은 Verheyden 등 $(2009)^{21)}$ 과 Saeys 등 $(2011)^{20)}$ 의 체간 훈련 운동을 본 연구에 맞게 수정 보완하여 적용하였다(Table 2)

\section{3. 평가방법}

본 연구에서는 뇌졸중 환자의 균형능력을 평가하기 위해 일어 나 걸어가기 검사(Time Up \& Go Test, TUG)와 에너지 소 모량을 평가하기 위해 산소 소모비와 에너지소비지수를 사용하 였다.

\section{1) 동적 균형능력 검사}

일어나 걸어가기 검사는 동적 균형능력을 알아보는 평가 방법 으로 기본적인 운동성과 균형 능력을 빠르게 측정할 수 있는 검사방법이다. 측정자 내 신뢰도는 $\mathrm{r}=.99$ 이고, 측정자간 신뢰 도는 $r=.98$ 로 신뢰할 만한 도구이다. 본 연구에서 대상자는

Table 1. General characteristics of the subjects

\begin{tabular}{cccccc}
\hline Subject & Gender & Age & Affected side & Onset(weeks) & K-MMSE \\
1 & Male & 57 & Rt.side & 32 & 26 \\
2 & Female & 51 & Lt.side & 39 & 27 \\
\hline
\end{tabular}

Table 2. Trunk training exercise program

Warm-up

Trunk training exercise

\section{Stretching exercise, Free exercise}

-Supine position-

- Lifting pelvis in crook lying with both feet supported

- Unilateral pelvic bridging

- Lifting shoulder girdle symmetrically and asymmetrically

-Sitting position-

- Anterior and posterior tilt of the pelvis

$30 \mathrm{~min}$

- Selective lengthening and shortening of on side of the trunk

- Lateral pelvic tilt without losing balance

- Rotation of the upper and lower part of the trunk

- Anterior and lateral reaching within and out of arm's reach

- Shuffling forward and backward

Cool-down
$5 \mathrm{~min}$ 
"시작"이라는 구령에 의해 의자에서 일어나 전방 $3 \mathrm{~m}$ 를 걸어간 후 돌아와 의자에 다시 앉는 시간을 측정하였으며, 3 회 측정하 여 평균값을 사용 하였다. ${ }^{27)}$

\section{2) 산소 소모비 측정}

편안한 속도로 트레드밀 보행 중 산소 소모비를 측정하기 위해 단위 거리 당 요구되는 산소 소모량을 측정하였으며 단위는 $\mathrm{ml} / \mathrm{kg} / \mathrm{m}$ 를 사용하였다. 측정 장비는 자동 호흡가스분석장치 (Quinton 5000, CARDIAC SCIENCE, USA)를 사용하였으 며, 측정 공간은 실내로 외부와 차단되어 있으며 평균온도 $25.8^{\circ} \mathrm{C}$, 평균습도는 $67.5 \%$ 이었다. 호흡 가스 분석을 위해 노 즐이 연결된 마스크를 안면에 밀착 착용 후 입과 코 주변에서 공기 노출 없는 것을 확인 하였고, 트레드밀을 이용하여 편안 한 속도로 5 분 보행 하는 중 마지막 2 분을 30 초 단위로 산소 소모비를 측정 하였다. ${ }^{28)}$

\section{3) 에너지소모지수 측정}

에너지소모지수를 평가하기 위해 대상자의 심박수를 측정하기 위해 환자의 가슴에 4 개의 패드를 부착하여 의자에 편안한 상 태로 휴식을 취한 후 안정기 심박수를 5 분간 측정하여 마지막 3 분에 대한 분당 평균 심박수를 측정하였다. 편안한 속도로 트 레드밀에서 5 분 보행 중 편안한 속도로 5 분 동안 트레드밀 보 행에서 마지막 3 분에 대한 분당 평균 심박수를 측정하였다. 측 정 장비는 자동 호흡가스분석장치를 사용하였으며, 보행 시 분 당 평균 심박수에서 안정 시 분당 평균 심박수 차이를 보행 속 도로 나눈 값으로 측정 하였다. ${ }^{29)}$
에너지소모지수(EEI)

$=\frac{\text { 보행중 심박수 }(\mathrm{beat} / \mathrm{min})-\text { 안정기 심박수 }(\mathrm{beat} / \mathrm{min})}{\text { 보행속도 }(\mathrm{m} / \mathrm{s})}$

\section{4. 분석 방법}

본 연구는 체간 훈련 운동이 동적 균형능력과 에너지 소모에 미치는 효과를 알아보기 위해 각각의 회기 동안 결과를 기록하 고 측정된 자료를 그래프를 이용하여 시각적 분석방법을 이용 하여 대상자를 분석하였다. 기술통계량을 통해 각 변수들의 기 간 내 평균값을 계산하여 각 단계의 변화율을 비교하여 제시하 였다.

\section{III. 결 과}

\section{1. 동적 균형능력 변화}

동적 균형능력 검사의 측정결과 대상자 1 은 기초선 $\mathrm{A}$ 에서 30.38 초, 중재기 $\mathrm{B}$ 에서는 26.44 초, 회귀기초선 $\mathrm{A}^{\prime}$ 에서는 26.62초로 나타났으며, 기초선 $\mathrm{A}$ 에 비해 중재기 $\mathrm{B}$ 는 $12.97 \%$ 가 감소되었고, 회귀기초선 $\mathrm{A}^{\prime}$ 는 $12.38 \%$ 가 감소된 것으로 나 타났다. 대상자 2 는 기초선 $\mathrm{A}$ 에서 32.6 초, 중재기 $\mathrm{B}$ 에서는 29.97초, 회귀기초선 $\mathrm{A}^{\prime}$ 에서는 28.26초로 나타났으며, 기초선 $\mathrm{A}$ 에 비해 중재기 $\mathrm{B}$ 는 $8.07 \%$ 가 감소되었고, 회귀기초선 $\mathrm{A}^{\prime}$ 는 $13.31 \%$ 가 감소된 것으로 나타났다(Table 3)(Fig 1).

Table 3. Variations of TUG

(unit: second)

\begin{tabular}{cccc} 
& Baseline A & Intervention B & Baseline A' \\
Subject 1 & $30.38 \pm 3.56$ & $26.44 \pm 2.45$ & $26.22 \pm 3.15$ \\
Subject 2 & $32.6 \pm 3.25$ & $29.97 \pm 2.59$ & $28.26 \pm 4.15$ \\
\hline
\end{tabular}

$\mathrm{M} \pm \mathrm{SD}$ : mean \pm standard deviation
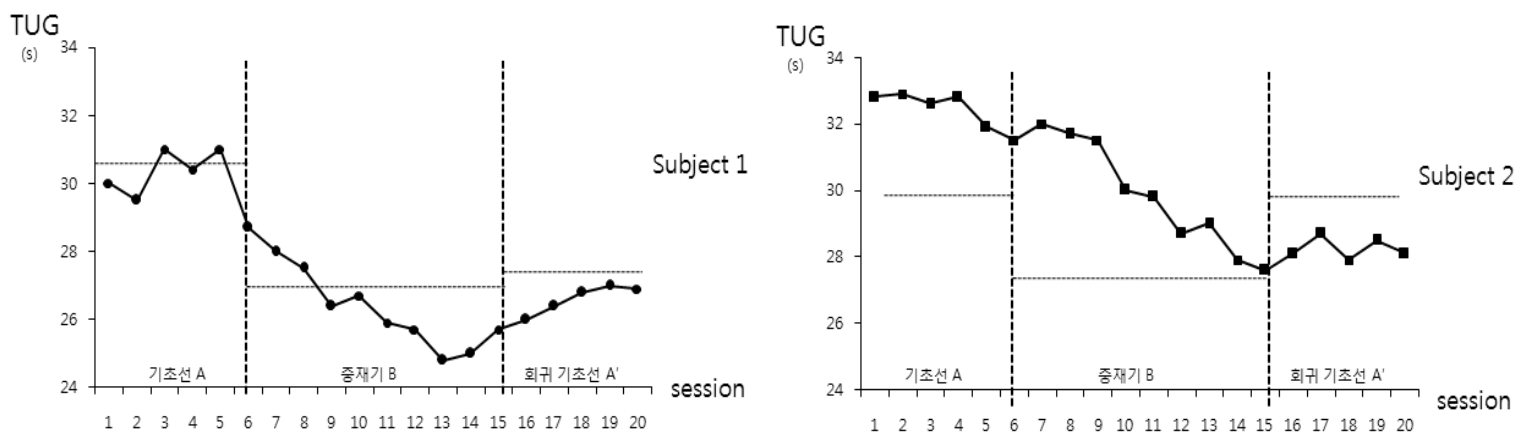

Figure 1. change of TUG in session 


\section{2. 산소 소모비 변화}

편안한 보행속도에서 산소 소모비 측정 결과 대상자 1 은 기초 선 $\mathrm{A}$ 에서 $0.42 \mathrm{ml} / \mathrm{kg} / \mathrm{m}$, 중재기 $\mathrm{B}$ 에서는 $0.34 \mathrm{ml} / \mathrm{kg} / \mathrm{m}$, 회 귀기초선 $\mathrm{A}^{\prime}$ 에서는 $0.33 \mathrm{ml} / \mathrm{kg} / \mathrm{m}$ 로 나타났으며, 기초선 $\mathrm{A}$ 에 비해 중재기 $\mathrm{B}$ 는 $19.04 \%$ 가 감소되었고, 회귀기초선 $\mathrm{A}^{\prime}$ 는 $21.43 \%$ 가 감소된 것으로 나타났다. 대상자 2 는 기초선 $\mathrm{A}$ 에서 $0.45 \mathrm{ml} / \mathrm{kg} / \mathrm{m}$, 중재기 $\mathrm{B}$ 에서는 $0.39 \mathrm{ml} / \mathrm{kg} / \mathrm{m}$, 회귀기초선 $\mathrm{A}^{\prime}$ 에서는 $0.4 \mathrm{ml} / \mathrm{kg} / \mathrm{m}$ 로 나타났으며, 기초선 $\mathrm{A}$ 에 비해 중재기 $\mathrm{B}$ 는 $13.33 \%$ 가 감소되었고, 회귀기초선 $\mathrm{A}^{\prime}$ 는 $11.11 \%$ 가 감소 된 것으로 나타났다(Table 4)(Fig 2).

\section{3. 에너지소모지수 변화}

편안한 보행속도에서 에너지소모지수 측정 결과 대상자 1 은 기 초선 $\mathrm{A}$ 에서 1.16beat $/ \mathrm{min}$, 중재기 $\mathrm{B}$ 에서는 0.86beat $/ \mathrm{min}$ 회귀기초선 $\mathrm{A}^{\prime}$ 에서는 $0.82 \mathrm{beat} / \mathrm{min}$ 로 나타났으며, 기초선 $\mathrm{A}$ 에 비해 중재기는 $25.86 \%$ 가 감소되었고, 회귀기초선 $\mathrm{A}^{\prime}$ 는 $29.31 \%$ 가 감소된 것으로 나타났다. 대상자 2 는 기초선 $\mathrm{A}$ 에서 $1.21 \mathrm{beat} / \mathrm{min}$, 중재기 $\mathrm{B}$ 에서는 $1.02 \mathrm{beat} / \mathrm{min}$, 회귀기초선 $\mathrm{A}^{\prime}$ 에서는 $0.95 \mathrm{beat} / \mathrm{min}$ 로 나타났으며, 기초선 $\mathrm{A}$ 에 비해 중재 기는 $15.7 \%$ 가 감소되었고, 회귀기초선 $\mathrm{A}^{\prime}$ 는 $13.31 \%$ 가 감소된 것으로 나타났다(Table 5)(Fig 3).

Table 4. Variations of 0xygen cost

(unit: $\mathrm{ml} / \mathrm{kg} / \mathrm{m}$ )

\section{Baseline A}

Intervention B

0.34

0.39

Subject 2

0.45

Subject 1

session

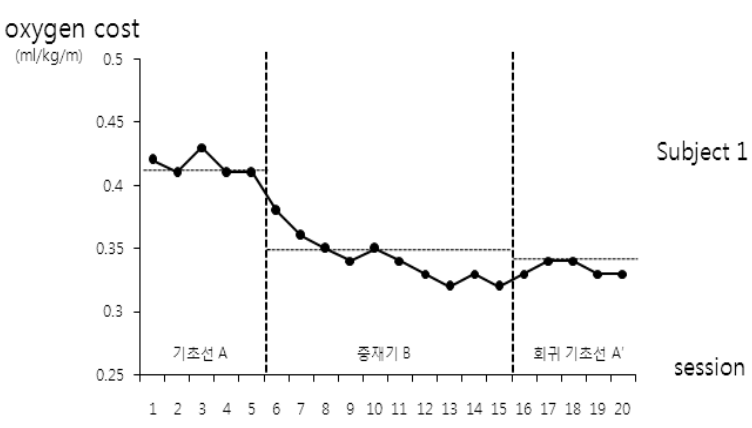

Figure 2. change of oxygen cost in session

Table 5. Variations of Energy expenditure index

(unit: beat/min)

\begin{tabular}{rccc} 
& Baseline A & Intervention B & Baseline A' \\
Subject 1 & 1.16 & 0.86 & 0.82 \\
Subject 2 & 1.21 & 1.02 & 0.95 \\
\hline
\end{tabular}

$\mathrm{M} \pm \mathrm{SD}$ : mean \pm standard deviation
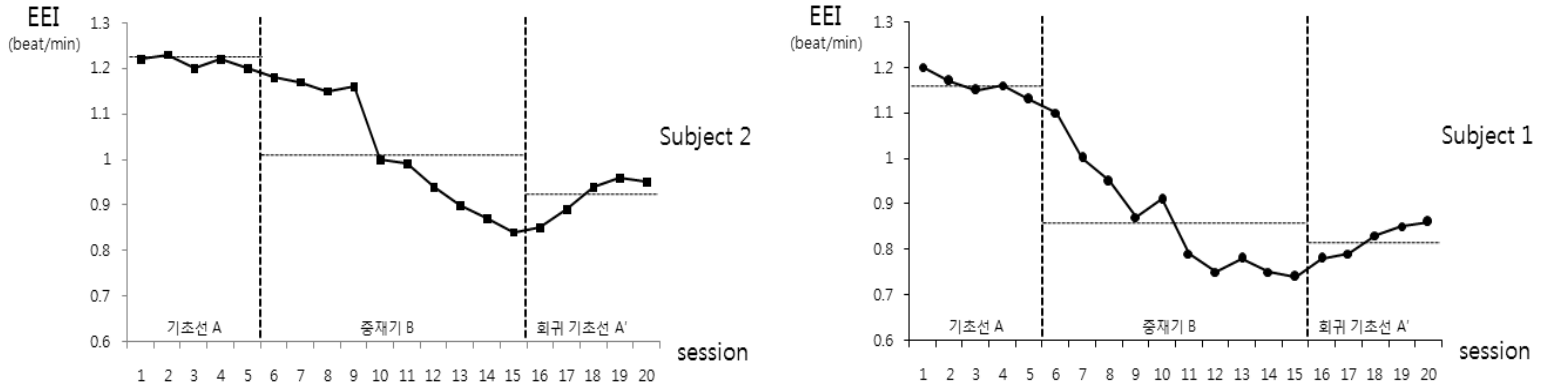

Figure 3. Change of energy expenditure index in session 


\section{IV. 고 찰}

체간 안정성에 관여하는 근육들은 자세조절을 위한 중심부위로 체간 하부와 골반 주변에 능동적 안정성을 제공하며 ${ }^{30)}$, 신체를 항중력 방향으로 바로 서게 하여 걷기와 달리기 등과 같이 자 세적 동요에 자동적으로 반응하여 주어진 과제를 정교하게 수 행할 수 있도록 돕는다. ${ }^{5)}$ 그러나 뇌졸중 환자는 상하지 뿐 아 니라 체간에도 근력 약화와 감각결손이 발생하며 균형과 보행 능력이 감소된다. ${ }^{2}$ 균형을 유지할 때 자세가 불안정해지면 과 도한 보상작용으로 굴근의 활성도가 증가되고 에너지 소모가 높아져 기능적인 움직임 시 쉽게 근 피로가 유발된다. ${ }^{31)}$ 뇌졸 중 환자의 피로 유발은 39 72\%에서 보고되고 있을 정도로 빈 번하며, 성공적인 재활치료에 장애 요인으로 환자의 삶의 질에 부정적인 영향을 미친다. ${ }^{32)}$ 따라서 일상생활에서 많은 부분을 차지하는 보행 중 발생하는 에너지 소모를 최소화 시키는 것은 근 피로를 줄이는데 중요한 요소이다. 이에 본 연구는 뇌졸중 환자에게 체간 훈련 운동을 적용하여 동적 균형능력과 에너지 소모에 미치는 효과를 알아보기 위해 시도되었다.

본 연구의 동적 균형능력 측정 결과 대상자 1 과 2 는 운동 을 시행하지 않는 기초선 기간보다 체간 훈련 운동을 시행하는 중재기 동안에 동적 균형능력이 향상되었고, 회귀 기초선 기간 에서도 중재기 동안에 향상된 동적 균형능력이 유지되는 것으 로 나타났다. 본 연구의 결과는 Chung 등 $(2013)^{33)}$ 이 뇌졸중 환자를 대상으로 체간 훈련 운동프로그램을 4 주간 적용하여 골 반의 후방경사를 통한 좌우 체중이동능력 개선으로 일어나 걸 어가기 검사 점수가 $33.06 \pm 18.39$ 에서 $27.64 \pm 13.73$ 으로 향상 되었다는 결과와 일치한다. 또한 Song과 $\mathrm{Kim}^{34)}$ 의 연구에서는 뇌졸중 환자를 대상으로 다양한 체간 훈련 운동을 8 주 동안 적 용한 결과 요부와 골반 주변의 올바른 자세정렬을 통한 동적 균형의 향상을 보고한 연구에서도 근거를 찾을 수 있다. 상하 지 근육에 비해 체간 근육은 대뇌에서 교차신경지배를 받기 때 문에 근육의 마비 정도가 상대적으로 심하지 않아 상하지 보다 쉽게 회복될 수 있다. ${ }^{35)}$ 이와 같이 체간 훈련 운동을 통해 요 부, 골반, 하지 사이의 협응된 움직임을 바탕으로 올바른 자세 재 정렬과 선행성 자세조절 기전을 활성화 시켜 동적 균형능력 이 향상된 것으로 사료된다.

본 연구의 산소 소모비 측정 결과 대상자 1 과 2 는 운동을 시행하지 않는 기초선 기간보다 체간 훈련 운동을 시행하는 중 재기 동안에 산소 소모비가 향상되었고, 회귀 기초선 구간에서 도 중재기 동안에 향상된 산소 소모비가 유지되는 것으로 나타 났다. 이러한 결과는 체간 훈련 운동이 보행 시 에너지 소모에 직접적인 영향을 주는 요인으로 볼 수 있다. Houdijk 등 $(2010)^{18)}$ 은 정상인인과 뇌졸중 환자를 대상으로 기립 상태를 유지할 때 사용되는 대사 에너지 소비를 측정한 결과, 균형능
력 저하가 있는 뇌졸중 환자가 정상인에 비해 더 많은 에너지 소비가 발생된다고 하였으며, 특히 뇌졸중 환자는 바닥의 상태 가 더 불안정하면 에너지소모가 최대 $52 \%$ 까지 증가됨을 보고 하였고, 효율적인 에너지소모를 위해 균형능력을 증진을 위한 운동방법의 필요성을 강조하였다. 본 연구에서도 체간 훈련 운 동을 통해 보행 시 산소 소모비가 감소된 것으로 나타나 보행 시 효율적인 에너지 소모가 이뤄진 것으로 사료된다. 또한, Ijmker 등 $(2013)^{36)}$ 은 정상인을 대상으로 트레드밀 보행훈련 시 대상자의 허리에 탄력적 벨트를 부착하여 외적 안정성을 제 공하였을 때가 그렇지 않았을 때보다 보행 에너지 소모가 감소 되는 결과가 나타났는데, 이는 동적 안정성이 요구되는 보행 시 외적 안정성 제공은 불필요한 보상작용을 줄여 에너지 소모 가 줄어든 결과라 할 수 있다. 인간의 정상적인 보행은 중추와 말초 신경계의 통합과정으로 균형을 유지하면서 신체를 원하는 장소로 이동시키는 과정으로, 하지의 교대적이고 리드미컬한 움직임을 통해 에너지 소모를 최소화 시킨다. ${ }^{37)}$ 그러나 뇌졸중 환자는 균형능력이 감소되고 불필요한 보상작용의 증가로 에너 지 소모량이 증가하게 되므로 정상인에 비해 에너지의 효율성 이 저하된다. ${ }^{38)}$ 따라서, 뇌졸중 환자의 균형능력 증진을 통한 독립적인 보행 능력 회복은 재활에 있어 중요한 요소 중 하나 이며 ${ }^{39)}$, 균형을 유지하며 최적의 에너지 소모를 통해 원하는 장소로 이동할 수 있는 보행능력의 습득은 매우 중요하다. ${ }^{40)}$ 본 연구에서 시행한 체간 훈련 운동도 다양한 체간 움직임을 시행함으로써 체간의 고유수용성감각이 활성화 되었으며, 체간 근육에 원심성, 구심성, 등척성 수축을 능동적으로 유도하여 체 간의 안정성이 증진되고, 균형유지를 위한 자세조절기전이 활 성화되어 보행 효율성이 향상된 것으로 사료된다.

보행의 효율성을 평가하는 중요한 지표로서 에너지 소모량 이 사용되고 있지만 측정 장비 사용의 번거로움 등의 이유로 뇌졸중 환자에서는 쉽게 적용하지 못하고 있다. 따라서 임상에 서 간편하게 에너지 소모량을 측정할 수 있는 방법으로 제시된 에너지소비지수는 심박수와 산소섭취량 사이에 1 차 선형 비례 가 있기 때문에 에너지 소모량을 지수화 하여 사용할 수 있 다. ${ }^{41)}$ 본 연구의 에너지소모지수 측정 결과 대상자 1 과 2 는 운 동을 시행하지 않는 기초선 기간보다 체간 훈련 운동을 시행하 는 중재기 동안에 동적 균형능력이 향상되었고, 회귀 기초선 구간에서도 중재기 동안에 향상된 에너지소모지수가 유지되는 것으로 나타났다. Lee와 Shin ${ }^{29)}$ 은 만성뇌졸중 환자를 대상으 로 좌우 대칭적인 움직임 증진과 불필요한 보상작용 감소를 위 해 6주간 매일 60분씩 컴퓨터 가상현실 운동프로그램을 적용 한 결과 에너지소모지수가 유의하게 감소하여 보행 시 효율성 이 증가되었다. 대칭적인 하지 움직임을 위한 선행요건으로 체 간 안정성이 필요한데, 본 연구에서 시행된 체간 훈련 운동도 체간 근육들을 강화하고 올바른 자세 정렬을 통해 보행 시 체 
간의 안정성을 바탕으로 에너지소모지수가 감소된 것으로 사료 된다. 균형장애로 불안정성이 증가되면 근육에서 발생하는 긴 장도, 협력수축, 항 중력 활동이 증가되고 관절 모멘트가 변경 되어 신체가 수행하는 일의 양이 증가하여 효율성이 감소 되지 만, 신체분절의 정확한 체 감각 정보를 통한 중추신경계의 자 세조절 능력의 향상은 신체의 안정성을 증진시켜 보행 시 하지 의 선택적인 움직임이 개선되고, 보행 시 에너지 소모를 최소 화 하는데 효과적이다. ${ }^{36)}$

본 연구에서 체간 훈련 운동 프로그램을 두 명의 만성뇌졸 중 환자에게 적용한 결과 동적균형이 향상 되었으며 에너지 소 모량을 나타내는 산소 소모비와 에너지소모지수가 모두 감소하 여 보행 에너지 효율성 측면에서 효과적 이었으며, 뇌졸중 환 자를 대상으로 에너지 소모를 감소시킬 수 있는 적절한 중재방 법으로 제시할 수 있다. 본 연구의 제한점으로는 대상자가 트 레드밀 보행이 가능한 환자 중 2 명으로 제한하였기 때문에 모 든 뇌졸중 환자들에게 적용하기에는 무리가 있으며, 반복되는 평가에 대해 학습화 과정을 적절하게 제한하지 못하였다. 또한 대상자가 본 참여하고 있다는 특별한 관심에 의한 호오손 효과 가 나타날 수 있었다. 향후 이러한 제한점을 보완하여 보행 효 율성 측면에서 에너지 소모를 최적화 할 수 있는 다양한 연구 가 활발하게 이루어 져야 할 것으로 생각된다.

\section{V. 결 론}

본 연구는 체간 훈련 운동이 두 명의 만성 뇌졸중 환자의 동적 균형과 에너지 소모에 미치는 영향을 알아보고자 하였다. 개별 실험 연구 설계 중 $\mathrm{ABA}$ 디자인을 사용하였고, 총 실험은 20 회기로 기초선 과정 5 회와 회귀과정 5 회는 체간 훈련 운동을 시행하지 않는 기초자료 수집기간이었고, 중재기 10 회는 주 5 일, 1 일 40 분씩 체간 훈련 운동을 시행하였다. 그 결과, 중재 기 동안의 체간 훈련 운동 시행 후 동적 균형능력이 향상되었 으며, 산소 소모비와 에너지소모지수 모두 감소하여 보행 시 에너지 소모가 감소된 것으로 나타났다. 또한 운동이 종료된 이후인 회귀 기초선 에서도 향상된 효과가 지속되는 것으로 나 타났다. 이러한 결과로 볼 때 추후 임상에서 체간 훈련 운동은 뇌졸중 환자의 에너지소모 측면에서 효과적인 운동 방법으로 제시될 수 있을 것으로 생각된다.

\section{References}

1. Tyson SF, Hanley M, Chillala J, et al. Balance disability after stroke. Phys Ther. 2006;86(1):30-8.

2. Dickstein R, Shefi S, Marcovitz E, et al. Anticipatory postural adjustment in selected trunk muscles in post stroke hemiparetic patients. Arch Phys Med Rehabil. 2004;85(2):261-7.

3. Tessem S, Hagstrøm N, Fallang B. Weight distribution in standing and sitting positions, and weight transfer during reaching tasks, in seated stroke subjects and healthy subjects. Physiother Res Int. 2007;12(2):82-94.

4. Hsieh CL, Sheu CF, Hsueh IP, et al. Trunk control as an early predictor of comprehensive activities of daily living function in stroke patients. Stroke. 2002;33(11):2626-30.

5. Verheyden G, Vereeck L, Truijen S, et al. Trunk performance after stroke and the relationship with balance, gait and functional ability. Clin Rehabil. 2006;20(5):451-8.

6. Verheyden G, Nieuwboer A, Mertin J, et al. The trunk impairment scale: a new tool to measure motor impairment of the trunk after stroke. Clin Rehabil. 2004;18(13):326-34.

7. Karthikbabu S, Rao BK, Manikandan N, et al. Role of trunk rehabilitation on trunk control, balance and gait in patients with chronic stroke: a pre-post design. Neuroscience and medicine. 2011;2(2):61-7.

8. Girolami GL, Shiratori T, Aruin AS. Anticipatory postural adjustments in children with hemiplegia and diplegia. J Electromyogr Kinesiol. 2011;21(6):988-97.

9. Waters RL, Mulroy S. The energy expenditure of normal and pathologic gait. Gait Posture. 1999;9(3):207-31.

10. Franceschini M, Massucci M, Ferrari L, et al. Effects of an ankle-foot orthosis on spatiotemporal parameters and energy cost of hemiparetic gait. Clin Rehabil. 2003;17(4):368-72.

11. Schepers VP, Visser-Meily AM, Ketelaar M, et al. Poststroke fatigue: course and its relation to personal and stroke-related factors. Arch Phys Med Rehabil. 2006;87(2):184-8.

12. van der Werf SP, van den Broek HL, Anten HW, et al. Experience of severe fatigue long after stroke and its relation to depressive symptoms and disease characteristics. Eur Neurol. 2001;45(1):28-33.

13. de Groot MH, Philips SJ, Eskes GA. Fatigue associated with stroke and other neurologic conditions: implications for stroke rehabilitation. Arch Phys Med Rehabil. 2003;84(11):1714-20.

14. Detrembleur C, Dierick F, Stoguart G, et al. Energy cost, mechanical work, and efficiency of hemiparetic walking. 
Gait Posture. 2003;18(2):47-55.

15. Waters RL, Mulroy S. The energy expenditure of normal and pathologic gait. Gait Posture. 1999;9(3):207-31.

16. Corcoran PJ, Jebsen RH, Brengelmann GL, et al. Effects of plastic and metal leg braces on speed and energy cost of hemiparetic ambulation. Arch Phys Med Rehabil. 1970;51(2):69-77.

17. Koyama K, Naito H, Ozaki H, et al. Effects of unstable shoes on energy cost during treadmill walking at various speeds. J Sports Sci Med. 2012;11(4):632-7.

18. Houdijk H, ter Hoeve N, Nooijen C, et al. Energy expenditure of stroke patients during postural control tasks. Gait Posture. 2010;32(3):321-6.

19. Houdijk H, Fickert R, van Velzen J, et al. The energy cost for balance control during upright standing. Gait Posture. 2009;30(2):150-4.

20. Saeys W, Vereeck L, Truijen S, et al. Randomized controlled trial of truncal exercises early after stroke to improve balance and mobility. Neurorehabilitation and Neural Repair. 2011;26(3):231-8.

21. Verheyden G, Vereeck L, Truijen S, et al. Additional exercises improve trunk performance after stroke: A pilot randomized controlled trial. Neurorehabilitation and Neural Repair. 2009;23(3):281-6.

22. Kim BH, Lee SM, Bae YH, et al. The effect of a task-oriented training on trunk control ability, balance and gait of stroke patients. J Phys Ther Sci. 2012;24(6):519-22.

23. Bayouk JF, Boucher JP, Leroux A. Balance training following stroke: effects of task-oriented exercises with and without altered sensory input. Int J Rehabil Res. 2006;29(1):51-9.

24. Yoo JS, Jeong JR, Lee WH. The Effect of trunk stabilization exercise using an unstable surface on the abdominal muscle structure and balance of stroke patients. J Phys Ther Sci. 2014;26(6):857-9.

25. Goljar N, Burger H, Rudolf M, et al. Improving balance in subacute stroke patients: a randomized controlled study. Int J Rehabil Res. 2010;33(3):205-10.

26. Chen IC, Cheng PT, Chen CL, et al. Effects of balance training on hemiplegic stroke patients. Chang Gung Med J. 2002;25(9):583-90.

27. Podsiadlo D, Richardson S. The timed "Up \& Go": a test of basic functional mobility for frail elderly persons. J Am Geriatr Soc. 1991;39(2):142-8.
28. Reisman DS, Rudolph KS, Farguhar WB. Influence of speed on walking economy poststroke. Neurorehabil Neural Repair. 2009;23(6):529-34.

29. Lee DY, Shin WS. The effects of virtual reality-based exercise on energy expenditure during gait in chronic stroke patients. Journal of Korea Academia-Industrial cooperation Society. 2010;11(10):3826-32.

30. Aluko A, DeSouza L, Peacock J. The effect of core stability exercises on variations in acceleration of trunk movement, pain, and disability during an episode of acute nonspecific low back pain: a pilot clinical trial. J Manipulative Physiol Ther. 2013;36(8):497-504.

31. Zamparo P, Francescato MP, De Luca G, et al. The energy cost of level walking in patients with hemiplegia. Scand J Med Sci Sports. 1995;5(6):348-52.

32. Snaphaan L, van der Werf S, de Leeuw FE. Time course and risk factors of post-stroke fatigue: a prospective cohort study. Eur J Neurol. 2011;18(4):611-7.

33. Chung EJ, Kim JH, Lee BH. The effects of core stabilization exercise on dynamic balance and gait function in stroke patients. $\mathrm{J}$ Phys Ther Sci. 2013;25(7):803-6.

34. Song JM, Kim SM. The effect of trunk stability exercise on balance and gait in stroke patients. J Korean Soc Phys Med. 2010;5(3):413-20.

35. Dickstein R, Heffes Y, Laufer Y, et al. Activation of selected trunk muscles during symmetric functional activities in poststroke hemiparetic and hemiplegic patients. J Neurol Neurosurg Psychiatry. 1999;66(2):218-21.

36. Ijmker T, Houdijk H, Lamoth CJ, et al. Energy cost of balance control during walking decreases with external stabilizer stiffness independent of walking speed. J Biomech. 2013;46(13):2109-14.

37. Kim EJ, Hwang BY, Kim JH. The effect of core strength exercises on balance and walking in patients with stroke. J Korean Soc Phys Ther. 2009;21(4):17-22.

38. da Cunha IT Jr, Lim PA, Qureshy H, et al. Gait outcomes after acute stroke rehabilitation with supported treadmill ambulation training: a randomized controlled pilot study. Arch Phys Med Rehabil. 2002;83(9):1258-65.

39. Goldie PA, Matyas TA, Evans OM. Deficit and change in gait velocity during rehabilitation after stroke. Arch Phys Med Rehabil. 1996;77(10):1074-82.

40. Saibene F. The mechanisms for minimizing energy 
expenditure in human locomotion. Eur J Clin Nutr. 1990;44:65-71.

41. Stoguart G, Detrembleur C, Lejeune TM. The reasons why stroke patients expend so much energy to walk slowly. Gait Posture. 2012;36(3):409-13. 